\title{
Fruit Quality in Almond as Related to the Type of Pollination in Self-compatible Genotypes
}

\author{
Ossama Kodad and Rafel Socias i Company ${ }^{1}$ \\ Unidad de Fruticultura, Centro de Investigación y Tecnología Agroalimentaria de Aragón (CITA), \\ Apartado 727, 50080 Zaragoza, Spain
}

\begin{abstract}
Additional Index words. Prunus amygdalus, self-pollination, inbreeding, nut traits, kernel traits, kernel composition, oil content, fatty acids

Abstract. Nut and kernel dimensions and sphericity, shelling percentage, oil content, and fatty acid composition were studied over 2 years in 15 advanced almond (Prunus amygdalus Batsch) selections. The aim was to test the effect of pollination type on these fruit traits for this group of new self-compatible selections of a mostly self-incompatible species as well as the yearly effect on these variables. Variability between selections was much higher than that between years, showing a moderate level of year-stability and a significant year effect only for some variables. The different pollination treatments affected all chemical components studied, as well as nut and kernel weight, but not the other physical traits. Self-pollination decreased kernel weight and volume as well as oil content and percentage of linoleic acid but increased the percentage of oleic acid. These variations in the fatty acid composition were in the trend of increasing kernel quality. Inbreeding depression could also negatively affect several aspects of nut and kernel quality. Thus, autogamous almond genotypes without apparent symptoms of inbreeding depression may yield kernels of increased nutritional and industrial quality.
\end{abstract}

Most almond breeding programs have fostered the development of self-compatible cultivars to overcome the problems related to cross-pollination of this mostly self-incompatible species (Socias i Company, 2002). Consequently, self-compatibility has been the primary trait considered during evaluation of seedlings in a breeding program (Socias i Company et al., 1998). However, any new self-compatible cultivar must meet all horticultural and commercial requirements to be valuable for the grower and the industry.

The main efforts in evaluating new self-compatible almond genotypes have been directed toward establishing their actual self-compatibility level. The first attempts focused on pollen tube growth, to ensure that this growth after self-pollination was similar to that after cross-pollination with a cross-compatible pollen and, thus, to confer a good self-compatibility level (Socias i Company et al., 1976). Additionally, this good pollen tube growth after self-pollination had to result in similar fruit sets, which may not always be the case (Socias i Company and Felipe, 1987). Furthermore, fruit set should reach the level of a commercial crop (Socias i Company and Felipe, 1992). From a commercial point of view, self-compatibility must consider not only the crop level but also that this crop must be of an acceptable quality. However, this aspect has not yet received much attention, probably because standards of almond fruit quality have been based on physical parameters (Socias i Company et al., 1998) and because differences in consumer preferences make a universal definition of fruit quality difficult, even ephemeral (Janick, 2005; Socias i Company et al., 2008).

Received for publication 7 Dec. 2007. Accepted for publication 5 Feb. 2008. This work was supported by grant AGL2004-06674-C02-01 of the Spanish Interministerial Commission for Science and Technology (CICYT).

O.K. gratefully acknowledges a scholarship from the Spanish National Institute for Agricultural and Food Research and Technology (INIA) and of the Consolidated Research Group A12 of Aragón. Technical assistance by O. Frontera and J. Búbal is gratefully acknowledged.

${ }^{1}$ Corresponding author. E-mail: rsocias@aragon.es.
Very few studies have considered almond fruit characteristics in relation to pollination type. Fruit development can be irregular after self-pollination (Grasselly and Olivier, 1988), resulting in smaller kernels (Torre Grossa et al., 1994). Thus, all these negative effects must be considered and evaluated before any new cultivar release. Although Torre Grossa et al. (1994) remarked the negative effect of self-pollination of 'Lauranne' in its final fruit size in a single year, Legave et al. (1997) did not find any difference in this same cultivar during 3 years. Dicenta et al. (2002) included this and five other genotypes in their 1year study, and found no difference between self- and crosspollination for several fruit traits, including fruit weight, kernel weight, shelling percentage, double kernels, empty nuts, and split kernels. All these studies have considered only physical traits, but there is not yet any information on the chemical composition of the kernels as a function of pollination type. However, kernel composition in relation to its possible industrial utilization (Alessandroni, 1980) or quality stability (Kester et al., 1993) must be taken into account when evaluating the actual effect of self-compatibility on the agronomical and commercial qualities of any new cultivar.

As a consequence, our objective was to ascertain the effect of each type of pollination not only on the physical traits of the fruit and the kernel but also on the kernel chemical traits in several almond genotypes previously selected because of their high self-compatibility level. This information will be essential in evaluating the fruit and kernel quality of any new selfcompatible cultivar-before further planting is recommended - to ensure a high-quality crop under all growing and pollination conditions.

\section{Materials and Methods}

Sixteen advanced selections coming from the cross between 'Bertina', a Spanish local selection, and 'Felisia,' a release from the Centro de Investigación y Tecnología Agroalimentaria de Aragón (CITA) breeding program, were included in this study. 
These selections were grafted onto the peach [Prunus persica (L.) Batsch] $\times$ almond hybrid rootstock 'Garnem' and grown in blocks of three trees in an alluvial loamy soil.

Nuts were harvested at maturity, when fruit mesocarp was fully dried and split along the fruit suture and peduncle abscission was complete (Felipe, 1977). During two consecutive years, a sample of 20 fruit was collected randomly around the canopy from a plant after open pollination to study the stability of the studied traits for each genotype over the 2 years. Additionally, samples of 20 fruit were collected after three different pollination treatments-open pollination, manual self-pollination, and cross-pollination with 'Cavaliera' pollen- to ascertain the effect of each type of pollen on expression of the studied traits. As much as possible, homogeneous branches were used for artificial pollinations, and the different treatments were applied to two branches as described by Socias i Company et al. (2004).

Length, width, and thickness were measured with a precision of $0.01 \mathrm{~mm}$ in all nuts with a digital caliper. After measurements, nuts were cracked to obtain the kernel and determine the shelling percentage by weight using an electronic balance. Length, width, and thickness were similarly measured in all kernels. These variables allowed determination of the sphericity index (geometric diameter/length) of fruit and kernel, which is used to define their shape.

For chemical analysis, two replicates of 20 fruit of each genotype were randomly collected and dried for $2 \mathrm{~d}$. After they had been blanched, the kernels were ground in an electric grinder. Oil was extracted from 4-5 g of ground almond kernels in a commercial fat extractor (Selecta, Barcelona, Spain) for $2 \mathrm{~h}$ using petroleum ether as solvent and keeping the heating source at $135^{\circ} \mathrm{C}$. Fat content was expressed as the difference in weight of the dried kernel sample before and after extraction. The oil sample was used to prepare the methyl esters of the corresponding fatty acids (FAMEs) according to the European Union official method (European Economic Community, 1991). The methyl esters were determined by gas chromatography with flame ionization using a SP2330 column $(30 \mathrm{~m} \times 0.25 \mathrm{~mm}$ i.d., $0.2 \mathrm{~m}$ film thickness) (Supelco, Bellfonte, PA). The carrier gas was helium at a flow rate of $2 \mathrm{~mL} \cdot \mathrm{min}^{-1}$. Heptadecanoic acid (C17:0) was used as internal standard. Identification of FAMEs was achieved by comparing with relative retention times in a reference sample that contained standard methyl esters (SigmaAldrich, Madrid, Spain).

Data were statistically analyzed by the General Linear Model procedure of SAS (version 9.1; SAS Institute, Cary, NC). Mean values were compared by Fisher's least-significant difference (LSD) multiple-range test.

\section{Results}

GENOTYPIC AND ENVIRONMENTAL VARIABILITY. As expected, all nut and kernel traits showed great variability between selections, reflecting each selection genotype (Table 1). However, differences between years, which are important for establishing trait stability, were much lower (Table 2).

The statistical analysis of the physical traits showed that the effect of genotype, year, and the interaction genotype $\times$ year were significant (Table 3 ). The year effect was stronger on the nut and kernel weight than on their shape, which is maintained despite variations in linear dimensions used for calculation of sphericity (data not shown). Shelling percentage, used as a quantitative measure of shell hardness, showed a higher yearto-year variability than the other traits. As a whole, the nut and kernel traits considered showed higher values in 2005 than in 2004 , independently of pollination treatment (Table 2).

The effects of genotype and year and the interaction genotype $\times$ year were significant for oil content (Table 4). As expected, oil content and fatty acid composition varied significantly among genotypes, agreeing with the results of Abdallah et al. (1998) in California almond cultivars. Oil content from 2005 harvest was slightly higher than that from 2004 (Table 2), with significant differences among years (Table 4). The genotype effect was significant for the different fatty acids, showing the particular fatty acid profile of each selection. The major differences in fatty acid composition among genotypes were observed for oleic (C18:1) and linoleic (C18:2) acids. The year effect differed depending on the fatty acid, being highly significant for oleic and palmitic acids, less significant for linoleic acid, and not significant for stearic acid. However, some selections did not show significant fluctuations between the 2 years (Table 3 ).

Pollen effect On NUT AND Kernel traits. Nut and kernel weight, but not other physical traits, showed significant differences between different pollination types (Table 3), although mean LSD separation indicated that the values of the different traits were slightly higher after cross-pollination than after selfpollination (Table 2). Some selections showed differences between treatments higher than $20 \%$ (data not shown), mainly for the more variable traits of nut and kernel weight. The differences found between the two artificial pollinations and open pollination were also significant only for nut and kernel weight. The interaction genotype $\times$ treatment was significant for all studied traits, except for shelling percentage and kernel sphericity (Table 3 ), showing that the values of the physical traits of the fruit coming from the different pollination types change their range depending on each selection. The interaction year $\times$ treatment was significant for fruit and kernel weight and shelling percentage but not for sphericity index (Table 3 ), thus indicating the important role of the year conditions in determining the physical traits of the nut independently of pollination type. The year effect was not significant for nut shape. On the other hand, despite the significance of the interaction year $x$ treatment, values of in-shell and kernel weights after selfpollination were lower than those obtained after cross-pollination. In 2005, the comparison of the percentage of defective kernels between treatments showed that the highest values were obtained after self-pollination and the lowest ones after crosspollination (Table 2).

Analysis of variance showed a significant effect of type of pollination on kernel chemical composition (Table 4), indicating a possible influence of pollen origin on almond kernel quality. Kernel taste did not show any difference between treatments (data not shown), but oil content and percentages of the different fatty acids were significantly affected by pollination type (Table 2). In general, cross-pollination slightly increased the percentage of kernel oil content, as it happened with the physical traits. However, in some selections, the oil percentage was higher in kernels coming from self-pollination. In most selections, self-pollinated kernels showed higher oleic acid content and lower linoleic acid content than did crosspollinated kernels. The interaction genotype $\times$ treatment was significant for all the studied traits (Table 4), showing that their range of values may change depending on each selection. The 
Table 1. Two-year average values of physical and chemical nut and kernel traits of 15 almond selections.

\begin{tabular}{|c|c|c|c|c|c|c|c|c|c|c|c|}
\hline \multirow[b]{2}{*}{ Selection } & \multicolumn{6}{|c|}{ Physical traits } & \multicolumn{5}{|c|}{ Chemical traits } \\
\hline & $\begin{array}{l}\text { In-shell } \\
\text { wt (g) }\end{array}$ & $\begin{array}{l}\text { Kernel } \\
\text { wt (g) }\end{array}$ & $\begin{array}{c}\text { Shelling } \\
\text { percentage }(\%)\end{array}$ & $\begin{array}{c}\text { Fruit } \\
\text { sphericity }\end{array}$ & $\begin{array}{c}\text { Kernel } \\
\text { sphericity }\end{array}$ & $\begin{array}{c}\text { Defective } \\
\text { kernels (\%) }\end{array}$ & $\begin{array}{l}\text { Oil content } \\
\text { ( } \% \text { dry wt) }\end{array}$ & $\begin{array}{l}\text { Oleic } \\
\text { acid } \\
(\% \text { oil })\end{array}$ & $\begin{array}{c}\text { Linoleic } \\
\text { acid } \\
(\% \text { oil })\end{array}$ & $\begin{array}{c}\text { Palmitic } \\
\text { acid } \\
\text { (\% oil) }\end{array}$ & $\begin{array}{c}\text { Stearic } \\
\text { acid } \\
(\% \text { oil })\end{array}$ \\
\hline G-1-23 & 3.45 & 0.85 & 25.05 & 0.68 & 0.56 & 13.00 & 61.23 & 77.10 & 14.57 & 5.47 & 1.89 \\
\hline G-1-41 & 4.10 & 1.04 & 25.76 & 0.70 & 0.56 & 19.40 & 56.92 & 76.20 & 13.77 & 6.24 & 1.75 \\
\hline G-2-1 & 5.43 & 1.23 & 23.22 & 0.67 & 0.53 & 13.80 & 56.27 & 70.16 & 20.50 & 6.27 & 1.59 \\
\hline G-2-22 & 3.21 & 0.91 & 29.99 & 0.70 & 0.59 & 9.30 & 56.46 & 75.77 & 15.04 & 6.32 & 1.52 \\
\hline G-2-25 & 4.49 & 1.06 & 24.30 & 0.67 & 0.55 & 5.40 & 59.46 & 75.56 & 15.28 & 6.15 & 1.93 \\
\hline $\mathrm{G}-3-28$ & 6.13 & 1.53 & 26.17 & 0.61 & 0.48 & 17.90 & 57.55 & 76.45 & 15.65 & 6.00 & 1.37 \\
\hline $\mathrm{G}-3-3$ & 4.49 & 1.17 & 26.65 & 0.69 & 0.56 & 6.80 & 55.73 & 74.04 & 15.93 & 6.31 & 1.90 \\
\hline G-3-4 & 4.56 & 1.23 & 27.08 & 0.68 & 0.56 & 11.10 & 56.56 & 66.44 & 23.65 & 6.39 & 1.59 \\
\hline G-3-8 & 5.80 & 1.63 & 26.11 & 0.68 & 0.53 & 12.00 & 56.52 & 75.86 & 15.28 & 5.86 & 1.48 \\
\hline
\end{tabular}

Table 2. Average values of physical and chemical nut and kernel traits for 20 kernels of 15 almond selections depending on type of pollination and year of study.

\begin{tabular}{|c|c|c|c|c|c|c|}
\hline \multirow[b]{4}{*}{ Trait } & \multicolumn{6}{|c|}{ Year } \\
\hline & \multicolumn{3}{|c|}{2004} & \multicolumn{3}{|c|}{2005} \\
\hline & \multicolumn{3}{|c|}{ Treatment } & \multicolumn{3}{|c|}{ Treatment } \\
\hline & $\otimes^{z}$ & $\times$ & $\square$ & $\otimes$ & $x$ & $\square$ \\
\hline \multicolumn{7}{|l|}{ Physical traits } \\
\hline In-shell wt (g) & $4.18 \mathrm{~b}^{\mathrm{y}}$ & $4.39 \mathrm{a}$ & $4.42 \mathrm{a}$ & $4.48 \mathrm{~b}$ & $4.73 \mathrm{a}$ & $4.49 \mathrm{~b}$ \\
\hline Kernel wt (g) & $1.07 \mathrm{~b}$ & $1.14 \mathrm{a}$ & $1.16 \mathrm{a}$ & $1.10 \mathrm{c}$ & $1.21 \mathrm{a}$ & $1.15 \mathrm{~b}$ \\
\hline Shelling percentage (\%) & $25.89 \mathrm{a}$ & $26.37 \mathrm{a}$ & $26.15 \mathrm{a}$ & $24.89 \mathrm{a}$ & $25.01 \mathrm{a}$ & $25.43 \mathrm{a}$ \\
\hline Fruit sphericity & $0.69 \mathrm{a}$ & $0.70 \mathrm{a}$ & $0.70 \mathrm{a}$ & $0.66 \mathrm{a}$ & $0.67 \mathrm{a}$ & $0.67 \mathrm{a}$ \\
\hline Kernel sphericity & $0.55 \mathrm{a}$ & $0.55 \mathrm{a}$ & $0.55 \mathrm{a}$ & $0.54 \mathrm{a}$ & $0.54 \mathrm{a}$ & $0.55 \mathrm{a}$ \\
\hline Defective kernels (\%) & - & - & - & $15.73 \mathrm{a}$ & $9.87 \mathrm{c}$ & $11.47 \mathrm{~b}$ \\
\hline \multicolumn{7}{|l|}{ Chemical traits } \\
\hline Oil content ( $\%$ dry wt) & $57.53 \mathrm{~b}$ & $58.10 \mathrm{a}$ & $57.29 \mathrm{~b}$ & $56.10 \mathrm{~b}$ & $57.24 \mathrm{a}$ & $56.97 \mathrm{~b}$ \\
\hline Palmitic acid (\% oil) & $5.68 \mathrm{~b}$ & $6.10 \mathrm{a}$ & $5.71 \mathrm{~b}$ & $6.59 \mathrm{~b}$ & $7.11 \mathrm{a}$ & $5.79 \mathrm{c}$ \\
\hline Palmitoleic acid (\% oil) & $0.48 \mathrm{~b}$ & $0.59 \mathrm{a}$ & $0.55 \mathrm{a}$ & $0.49 \mathrm{~b}$ & $0.53 \mathrm{a}$ & $0.52 \mathrm{a}$ \\
\hline Stearic acid (\% oil) & $1.66 \mathrm{c}$ & $1.74 \mathrm{a}$ & $1.69 \mathrm{~b}$ & $1.59 \mathrm{c}$ & $1.71 \mathrm{~b}$ & $1.84 \mathrm{a}$ \\
\hline Oleic acid (\% oil) & $76.45 \mathrm{a}$ & $73.70 \mathrm{~b}$ & $74.55 \mathrm{~b}$ & $75.42 \mathrm{a}$ & $73.51 \mathrm{~b}$ & $73.30 \mathrm{~b}$ \\
\hline Linoleic acid (\% oil) & $15.01 \mathrm{~b}$ & $15.96 \mathrm{~b}$ & $16.03 \mathrm{a}$ & $15.36 \mathrm{c}$ & $16.01 \mathrm{~b}$ & $18.03 \mathrm{a}$ \\
\hline
\end{tabular}

${ }^{\mathrm{z}} \otimes=$ self-pollination, $\times=$ cross-pollination, $\square=$ open pollination.

${ }^{\mathrm{y}}$ Mean separation for each trait by LSD multiple-range test at $P \leq 0.05$.

effect of the pollen source on oleic acid content was verified at the individual level, showing that the self-pollinated kernels had higher amounts of oleic acid (Table 2). This situation was maintained in both years. Conversely, the significance of the interaction genotype $\times$ treatment $\times$ year showed that variations in oil content and in oleic acid percentage of each genotype were affected by external conditions independently of the treatment.

\section{Discussion}

VARIABILITY. The significance of the genotype effect on the physical traits considered agreed with the results previously reported (Dicenta et al., 1993; Kester et al., 1977). However, the significant year effect on fruit and kernel size is probably due to changes in the environmental conditions because a strong environmental and seasonal component has been described for fruit and kernel (Dicenta et al., 1993), as well as for crop load, tree vigor, and soil moisture (Kester and Gradziel, 1996). The non- or less-significant year effect on the nut and kernel sphericity index, used to evaluate their shape, showed that shape is constant over the years, thus being reasonably considered a cultivar trait (Gülcan, 1985). However, the differences for kernel weight between years may not be important from a commercial point of view because most genotypes present kernel weights higher than $1 \mathrm{~g}$, considered an objective in almond breeding programs.

In addition to the year-to-year fluctuation of these physical traits, there is a significant year $\times$ genotype interaction (Table 3), indicating a different genotypic behavior in relation to the environment, because a tree is a biological entity whose behavior is not mechanically controlled (Socias i Company et al., 2004).

Oleic acid content, the highest of all fatty acids, showed a significant year effect. Year variability for linoleic acid content, the second-highest in total amount, was significant only at the $5 \%$ level. These are also the most important fatty acids because of their implication in oil quality, as a higher ratio of oleic-tolinoleic acids is associated with higher oil stability and lower rancidity (Kester et al., 1993) as well as with a higher nutritional value (Vezvaei and Jackson, 1996).

Crop load has been related to kernel weight, but our results do not show any correlation of fruit set with kernel chemical composition. Fruit set showed a significant positive correlation with oil content only in the first year (Table 5), indicating that 
Table 3. Analysis of variance of physical nut and kernel traits of 15 almond selections.

\begin{tabular}{|c|c|c|c|c|c|c|}
\hline \multirow[b]{2}{*}{ Source of variation } & \multirow[b]{2}{*}{$\mathrm{df}$} & \multicolumn{5}{|c|}{ Mean squares } \\
\hline & & In-shell wt & Kernel wt & Shelling percentage & Fruit sphericity & Kernel sphericity \\
\hline Genotype & 14 & $86.41 * * *$ & $4.80 * * *$ & $3297.5 * * *$ & $0.115 * * *$ & $0.091 * * *$ \\
\hline Year & 1 & $31.32 * *$ & $0.08 * *$ & $2178.5^{* * *}$ & $0.383^{\mathrm{NS}}$ & $0.038 *$ \\
\hline Treatment & 2 & $09.75^{* * *}$ & $0.81 * * *$ & $3311.1^{\mathrm{NS}}$ & $0.009^{\mathrm{NS}}$ & $0.003^{\mathrm{NS}}$ \\
\hline Genotype $\times$ treatment & 28 & $42.64 * * *$ & $0.19 * * *$ & $3321.9^{\mathrm{NS}}$ & $0.002 * *$ & $0.002^{\mathrm{NS}}$ \\
\hline Year $\times$ treatment & 2 & $46.74 * * *$ & $0.73 * * *$ & $3366.3^{*}$ & $0.001^{\mathrm{Ns}}$ & $0.003^{\mathrm{NS}}$ \\
\hline Residual & 1710 & 0.31 & 0.025 & 21.76 & 0.0006 & 0.002 \\
\hline
\end{tabular}

$\overline{\mathrm{Ns}, * *, * * *}$ Nonsignificant or significant at $P \leq 0.01$ or 0.001 , respectively.

Table 4. Analysis of variance of fatty composition of 15 almond selections.

\begin{tabular}{lrccccc}
\hline & & \multicolumn{5}{c}{ Mean squares } \\
\cline { 3 - 7 } Source of variation & df & content & acid & acid & acid & $\begin{array}{c}\text { Linoleic } \\
\text { acid }\end{array}$ \\
\hline Genotype & 14 & $40.3^{* * *}$ & $0.97^{* * *}$ & $0.91^{* * *}$ & $105.5^{* * *}$ & $89.9^{* * *}$ \\
Year & 1 & $27.7^{* * *}$ & $19.3^{* *}$ & $0.01^{\text {Ns }}$ & $74.44^{* *}$ & $28.8^{*}$ \\
Genotype $\times$ year & 14 & $05.8^{* *}$ & $0.24^{*}$ & $0.17^{* * *}$ & $05.56^{* * *}$ & $45.3^{* * *}$ \\
Treatment & 2 & $58.9^{* * *}$ & $11.1^{* * *}$ & $0.29^{* * *}$ & $059.5^{* * *}$ & $51.4^{* * *}$ \\
Genotype $\times$ treatment & 28 & $25.8^{* *}$ & $0.22^{*}$ & $0.05^{* * *}$ & $07.48^{* * *}$ & $47.6^{* * *}$ \\
Year $\times$ treatment & 2 & $3.4^{\text {Ns }}$ & $3.91^{* * *}$ & $0.21^{* * *}$ & $00.24^{\text {Ns }}$ & $16.5^{* * *}$ \\
Genotype $\times$ year $\times$ treatment & 28 & $3.4^{* * *}$ & $0.32^{* * *}$ & $0.07^{* * *}$ & $05.71^{* * *}$ & $44.1^{* * *}$ \\
Residual & 179 & 1.72 & 0.12 & 0.015 & 0.61 & 0.71 \\
\hline $\mathrm{Ns}^{* * * * * * * *}$ Nonsignificant & &
\end{tabular}

$\mathrm{Ns},, * *, *, * * *^{*}$ Nonsignificant or significant at $P \leq 0.05,0.01$, or 0.001 , respectively.

this correlation is due to an undefined environmental condition in 2004 and not to genetics. Another significant correlation was that of kernel weight and oil content in both years, but only for the open pollination treatment (Table 5). Abdallah et al. (1998) also reported a low correlation between kernel weight and oil content. However, only correlation coefficients higher than 0.71 or lower than -0.71 have been suggested to be biologically meaningful (Skinner et al., 1999), and in our results, all correlation coefficients were lower than 0.5 , thus showing their low biological value.

These results shows that kernel oil and fatty acid composition present a higher year-to-year stability than do physical traits, indicating that the chemical components depend more on genotype than on environmental conditions. From a breeding point of view, some selections (G-2-25, G-3-3, and I-3-27) showed a very good performance during the 2 years of study, thus offering opportunities for optimizing oil content and quality through genotypic selection.

Pollen effects on Physical traits. The pollen effect was significant on nut and kernel weight, with fruit coming from cross-pollination being heavier than that from self-pollination. The same results were found in other almond cultivars (Oukabli et al., 2002; Torre Grossa et al., 1994) and in other species, such as pecan [Carya illinoinensis (Wangenh.) K. Koch (Marquard, 1988)] and lychee [Litchi chinensis Sonn. (Stern et al., 1993)]. However, Legave et al. (1997) reported no negative effect of the self-pollen on the nut and kernel weight in 'Lauranne', in contrast to the results of Torre Grossa et al. (1994) in the same cultivar. Dicenta et al. (2002) reported no significant differences between self- and cross-pollination for nut and kernel weight in six self-compatibles genotypes, although they found that kernel weight after cross-pollination was heavier $(1.25 \mathrm{~g})$ than after selfpollination $(1.18 \mathrm{~g})$.

The same discrepancy was found when comparing the nut and kernel physical traits in fruit coming from the two pollination types. Vargas et al. (2005) reported that kernels from open pollination were heavier and larger than selfed nuts, agreeing with our results, although Ortega et al. (2006) found significant differences between open and self-pollination for nut weight but not for kernel weight. In addition, they found a significantly higher number of defective kernels after self-pollination than after open pollination, although they did conclude that self-pollination did not have any effect on fruit quality. The cited results were from a single year, but our results were not consistent over both years. In the first year, nut and kernel were heavier after cross-pollination, and in the second year, no differences were found for nut weight. This explains the significance of the interaction year $\times$ treatment. This situation could be due to the unknown ratio of selfed fruit in the open pollination treatment, because these selections show a high level of autogamy (Kodad, 2006). The pollen donor effect could explain these results; note that Vezvaei and Jackson (1995) reported that heavier nuts were produced by 'Price', which produces small nuts, when pollinated by 'Keane', a large-kernelled cultivar. In pistachio (Pistacia vera $\mathrm{L}$.) and chestnut (Castanea sativa Mill.), pollen from a small-seeded cultivar or species produced a decreased nut size when applied to a cultivar or species normally producing large seeds (Crane and Iwakiri, 1980). Rahemi and Mojadad (2001) reported that a pollen mixture of different cultivars affects significantly nut and kernel weight in hazelnut (Corylus avellana L.), stressing the importance of pollen on fruit characteristics.

The decrease in almond nut and kernel weight when comparing self- with cross-pollination has been attributed to inbreeding depression effects (Oukabli et al., 2002). The same hypothesis has been advanced in pear [Pyrus communis L. (Bell et al., 1981)]. Pollen source has been reported to affect the physical nut and kernel traits in self-incompatible cultivars (Eti et al., 1994; Kumar and Das, 1996; Vezvaei and Jackson, 1995), 
Table 5. Correlations between fruit set and different parameters of oil content and fruit physical traits in 2004 (value on top) and 2005 (value on bottom).

\begin{tabular}{|c|c|c|c|c|c|c|}
\hline \multirow[b]{2}{*}{ Trait } & \multicolumn{3}{|c|}{ Fruit set } & \multicolumn{3}{|c|}{ Oil content } \\
\hline & $\otimes^{z}$ & $x$ & $\square$ & $\otimes$ & $x$ & $\square$ \\
\hline \multirow[t]{2}{*}{ Oil content } & $0.41^{y}$ & 0.36 & 0.35 & - & - & - \\
\hline & 0.18 & 0.23 & -0.22 & - & - & 一 \\
\hline \multirow[t]{2}{*}{ In-shell wt } & 0.06 & -0.14 & -0.33 & 0.18 & -0.28 & -0.40 \\
\hline & 0.16 & -0.15 & -0.07 & -0.08 & -0.09 & -0.31 \\
\hline \multirow[t]{2}{*}{ Kernel wt } & -0.01 & -0.10 & -0.32 & 0.02 & -0.30 & -0.43 \\
\hline & 0.27 & -0.15 & 0.05 & -0.23 & -0.16 & -0.35 \\
\hline \multirow[t]{2}{*}{ Shelling percentage } & -0.17 & -0.12 & -0.29 & -0.26 & -0.31 & -0.13 \\
\hline & 0.06 & -0.01 & 0.17 & -0.19 & -0.32 & -0.01 \\
\hline \multirow[t]{2}{*}{ Fruit sphericity } & -0.28 & 0.26 & 0.18 & -0.06 & 0.24 & 0.02 \\
\hline & 0.22 & -0.02 & 0.31 & 0.02 & 0.02 & -0.28 \\
\hline \multirow[t]{2}{*}{ Kernel sphericity } & -0.31 & 0.13 & 0.23 & -0.12 & 0.12 & 0.12 \\
\hline & -0.16 & 0.02 & -0.03 & 0.13 & -0.06 & 0.12 \\
\hline
\end{tabular}

${ }^{\mathrm{z}} \otimes=$ self-pollination, $\times=$ cross-pollination, $\square=$ open pollination.

${ }^{y}$ All correlations in bold are significant at $P \leq 0.05$.

where self-pollination cannot be applied, indicating the existence of xenia effects in almond (Kumar and Das, 1996). In macadamia (Macadamia integrifolia Maiden \& Betche), mean fruit weight from mixed orchards of two or more cultivars is $14 \%$ higher than that from monocultivar orchards (Ito and Hamilton, 1980). These differences have been attributed to the positive effect of cross-pollination and not to inbreeding.

Cross-pollination has been considered to have a positive effect on the physical fruit characteristics in mandarin (Citrus reticulata Blanco) when compared with self-pollination (Vithanage, 1991; Wallace and Lee, 1999), and attributed to xenia (Wallace and Lee, 1999) because its own pollen did not dramatically affect fruit quality. However, in our study, the genotype $\times$ treatment interaction showed that these differences were significant in some selections and not in others. The decrease in kernel weight and the higher percentage of defective kernels after self-pollination could be due to inbreeding because different patterns of decrease or increase were observed in all selections, as suggested by Oukabli et al. (2002) in 'Tuono'. Ortega et al. (2006) found only an increase of defective kernels after self-pollination in two out of 26 genotypes. In addition, Alonso and Socias i Company (2005) studied the effect of inbreeding on self-compatibility expression in almond and found that only 10 out of 110 seedlings from the cross 'Ferralise' $x$ 'Tuono' showed anomalous growth after self-pollination as compared with cross-pollination. Kester and Asay (1975) and Grasselly and Olivier (1981) observed reduced vigor, weak vegetative growth, low bloom density, bark cracking, and gummosis only in some individuals in inbred offspring, as has also been observed in some families of the CITA breeding program having 'Tuono' in their genealogy. All of these observations indicate that the response of self-compatible genotypes to self-pollination may be due to the genetic characteristics of each genotype giving rise to different phenotypic expression in both kind and strength.

The lack of significant differences for the sphericity index between the fruit of the different treatments indicates that fruit and kernel shape is a clear cultivar trait (Gülcan, 1985) and is probably the reason that almond quality has to date been defined using only physical parameters (Socias i Company et al., 2008).
Pollen has been also reported not to affect nut and kernel shape in hazelnut (Rahemi and Mojadad, 2001).

Pollen effect on chemical traits. There were no differences in kernel taste between treatments, confirming that pollen type does not affect taste (Dicenta et al., 2000). However, the studies on the biosynthesis of the different chemical components of the almond kernel have been only focused on the process of accumulation of the different chemical fractions during fruit development (Saura Calixto et al., 1988) without considering the origin of these components. Dure (1975) pointed out that, during embryogenesis, in addition to the nutrients supplied by the mother plant, the embryo itself also synthesizes and stores an important fraction of nutrients. Saura Calixto et al. (1988) reported that oil accumulation takes place only when the cotyledon reaches a certain maturity level. This fact may suggest that the embryo contributes to oil kernel composition, thus being affected by both maternal and paternal genotypes.

The effect of self-pollination on chemical traits of the almond kernel has not yet been studied. Consequently, our results cannot be compared. However, Vezvaei and Jackson (1995) did not find any significant effect of pollen source on the chemical composition of 'Nonpareil' kernels. In other species, such as corn (Zea mays L.), some chemical components of the endosperm (Correns, 1901) and of the embryo (Curtis et al., 1956) are highly affected by the pollen origin. A higher protein content was found in corn kernels after self-pollination as compared with cross-pollination (East and Jones, 1920). In apple (Malus $\times$ domestica Borkh.), Davarynejad et al. (1994) reported that 'Gloster' pollen significantly increased the amount of vitamin C (ascorbic acid) in fruit of 'Duncan Red Delicious' and 'Idared' cultivars but decreased it in 'Golden Delicious'.

Although oil content in almond kernels obtained after selfpollination was lower that in those from cross-pollination, the significant interaction of genotype $\times$ treatment indicates that the genotype response to the different treatments depends on the specific characteristics of each genotype.

The fatty acid profile showed significant differences depending on the pollination treatment. Mean separation by LSD test showed an increase of all fatty acids, with the exception of oleic and stearic acids, after cross-pollination. These differences could be due to the accumulation of additive genes after selfpollination because these traits seem to be quantitative (Kester and Gradziel, 1996). In mandarin, fruit of 'Ellonor' after selfpollination showed a lower sugar content than after crosspollination (Wallace and Lee, 1999). The decrease in oleic acid percentage after cross-pollination agrees with the increase in linoleic acid because of the negative correlation between both percentages (Abdallah et al., 1998). In any case, the increase in oleic acid and the decrease in linoleic acid contents in selfpollinated kernels confer to them a higher nutritional value and a better stability against rancidity than kernels from open and cross-pollination. As a consequence, autogamous cultivars in solid orchards could supply a product of the highest nutritional and technological quality to the commercial and industrial sectors.

\section{Conclusion}

The effects of pollen on nut and kernel characteristics are known to occur in several nut crops. In almond, however, this 
phenomenon is under discussion. Our results confirm the significant effect of the type of pollen on the physical and chemical characteristics of almond fruit and show for the first time the possible positive effect of self-pollination on the fatty acid composition of the almond kernel, mainly on the increase of oleic acid content. The sharp decrease in weight and volume of the kernel after self-pollination in some genotypes points to the need for considering the possible effect of inbreeding on the expression of these traits, requiring careful evaluation in breeding programs where a reduced genetic pool of parents has been used as the source of self-compatibility and other horticultural and commercial traits (Kester et al., 1990; Socias i Company, 2002). Consequently, selection of autogamous cultivars without apparent symptoms of inbreeding depression must not affect kernel quality in almond but instead improve its nutritional and industrial quality.

\section{Literature Cited}

Abdallah, A., M.H. Ahumada, and T.M. Gradziel. 1998. Oil concentration and fatty acid composition of almond kernels from different genotypes and California production regions. J. Amer. Soc. Hort. Sci. 123:1029-1033.

Alessandroni, A. 1980. Le mandorle. Panificazione Pasticceria 8: 67-71.

Alonso, J.M. and R. Socias i Company. 2005. Differential pollen tube growth in inbred self-compatible almond genotypes. Euphytica 144:207-213.

Bell, R.L., J. Janick, R.H. Zimmerman, T. van der Zwet, and L.C. Blacke. 1981. Response of pear to inbreeding. J. Amer. Soc. Hort. Sci. 106:584-589.

Correns, C. 1901. Bastarde zwischen Maisrassen, mit besonder Berucksichtung der Xenien. Bibliotheca Bot. 53:1-161.

Crane, J.C. and B.T. Iwakiri. 1980. Xenia and metaxenia in pistachio. HortScience 15:184-185.

Curtis, J.J., A.M. Brunson, J.E. Hubbard, and F.R. Earle. 1956. Effect of the pollen parent on oil content of corn kernel. Agron. J. 48:551555.

Davarynejad, G.H., J. Nyéki, J.H. Szabó, and Z. Lakner. 1994. Relationship between pollen donors and quality of fruits of 12 apple cultivars. Acta Hort. 368:344-354.

Dicenta, F., J.E. García, and E. Carbonell. 1993. Heritability of fruit characters in almond. J. Hort. Sci. 68:121-126.

Dicenta, F., P. Martínez-Gómez, E. Ortega, and H. Duval. 2000. Cultivar pollinizer does not affect almond flavor. HortScience 35:1153-1154.

Dicenta, F., E. Ortega, J.A. Cánovas, and J. Egea. 2002. Selfpollination vs. cross-pollination in almond: Pollen tube growth, fruit set and fruit characteristics. Plant Breed. 121:163-167.

Dure, L.S. 1975. Seed formation. Annu. Rev. Plant Physiol. 26:259278.

East, E.M. and D.F. Jones. 1920. Genetic studies on the protein content of maize. Genetics 5:543-610.

European Economic Community. 1991. Commission Regulation (EEC) $2568 / 91$ of 11 July 1991 on the characteristics of olive oil and olive-residue oil and on the relevant methods of analysis. Offic. J. Eur. Union L248:1-83.

Eti, S., S. Paydaş, A.B. Küden, N. Kaşka, Ş. Kurnaz, and M. Ugin. 1994. Studies on fruit set and quality characteristics of some self and cross pollinated selected almond types. Acta Hort. 373:57-64.

Felipe, A.J. 1977. Almendro. Estados fenológicos. Inf. Técn. Econ. Agr. 27:8-9.

Grasselly, C. and G. Olivier. 1981. Difficulté de survie de jeunes semis d'amandier dans certaines descendances. Options Méditerranéennes, CIHEAM/IAMZ 81/I:65-67.

Grasselly, C. and G. Olivier. 1988. Phénomènes d'inbreeding dans les descendances issues d'autofécondation chez l'amandier. Agricul- ture, VII Colloque du GREMPA, Reus (Tarragona), Spain, 17-19 June. Rapport EUR, Commission des Communautés Européennes 11557:73-78.

Gülcan, R 1985. Almond descriptors (revised). International Board of Plant Genetic Resources, Rome.

Ito, P.J. and R.A. Hamilton. 1980. Quality and yield of 'Keauhou' macadamia nuts from mixed and pure block plantings. HortScience 15:307.

Janick, J. 2005. Breeding intractable traits in fruit crops: Dream the impossible dream. HortScience 40:1944.

Kester, D.E. and R.N. Asay. 1975. Almonds, p. 387-419. In: J. Janick and J.N. Moore (eds.). Advances in fruit breeding. Purdue Univ. Press, West Lafayette, IN.

Kester, D.E. and T.M. Gradziel. 1996. Almonds, p. 1-97. In: J. Janick and J.N. Moore (eds.). Fruit breeding, Vol. III. Wiley, New York.

Kester, D.E., P.E. Hansche, V. Beres, and R.N. Asay. 1977. Variance components and heritability of nut and kernel traits of almond. J. Amer. Soc. Hort. Sci. 102:264-266.

Kester, D.E., T.M. Gradziel, and C. Grasselly. 1990. Almonds (Prunus). Acta Hort. 290:699-758.

Kester, D.E., S. Cunningham, and A.A. Kader. 1993. Almonds, p. 121126. In: Encyclopedia of food science, food technology and nutrition. Academic Press, London.

Kodad, O. 2006. Criterios de selección y de evaluación de nuevas obtenciones autocompatibles en un programa de mejora genética del almendro. Univ. Lérida, Spain, PhD Diss.

Kumar, K. and B. Das. 1996. Studies on xenia in almond [Prunus dulcis (Miller) D.A. Webb]. J. Hort. Sci. 71:545-549.

Legave, J.V., J.C. Richard, J.P. Thermoz, and H. Duval. 1997. Lauranne 'Avijor' dans la course. Fruits Légumes 155:36-38.

Marquard, R.D. 1988. Outcrossing rates in pecan and the potential for increased yields. J. Amer. Soc. Hort. Sci. 113:84-88.

Ortega, E., P.J. Martínez-Garcia, and F. Dicenta. 2006. Influence of self-pollination in fruit quality of autogamous almonds. Scientia Hort. 109:293-296.

Oukabli, A., A. Lansari, D.L. Wallali, and A. Abousalem. 2002. Effects of controlled self-pollination and cross-pollination on fruit set, embryo viability and pomological traits in the self-compatible almond 'Tuono'. Acta Hort. 591:429-435.

Rahemi, M. and D. Mojadad. 2001. Effect of pollen source on nut and kernel characteristics of hazelnut. Acta Hort. 556:371-376.

Saura Calixto, F., J. Cañellas Mut, and L. Soler. 1988. La almendra: Composición, variedades, desarrollo y maduración. Instituto Nacional de Investigaciones Agrarias, Madrid, Spain.

Skinner, D.Z., G.R. Bauchan, G. Auricht, and S. Hughes. 1999. A method for the efficient management and utilization of a large germplasm collections. Crop Sci. 39:1237-1242.

Socias i Company, R., D.E. Kester, and M.V. Bradley. 1976. Effects of temperature and genotype on pollen tube growth of some selfcompatible and self-incompatible almond cultivars. J. Amer. Soc. Hort. Sci. 101:490-493.

Socias i Company, R. and A.J. Felipe. 1987. Self-compatibility in almond: Transmission and recent advances in breeding. Acta Hort. 244:307-317.

Socias i Company, R. and A.J. Felipe. 1992. Self-compatibility and autogamy in 'Guara' almond. J. Hort. Sci. 67:313-317.

Socias i Company, R., A.J. Felipe, J. Gómez Aparisi, J.E. García, and F. Dicenta. 1998. The ideotype concept in almond. Acta Hort. 470:51-56.

Socias i Company, R. 2002. Latest advances in almond self-compatibility. Acta Hort. 591:205-211.

Socias i Company, R., J.M. Alonso, and J. Gómez Aparisi. 2004. Fruit set and productivity in almond as related to self-compatibility, flower morphology and bud density. J. Hort. Sci. Biotechnol. 79:754-758.

Socias i Company, R., O. Kodad, J.M. Alonso, and T.M. Gradziel. 2008. Almond quality: A breeding perspective. Hort. Rev. (Amer. Soc. Hort. Sci.) 34:197-238. 
Stern, R.A., S. Gazit, R. El-Batsri, and C. Degani. 1993. Pollen parent effect on outcrossing rate, yield, and fruit characteristics of 'Floridian' and 'Mauritius' lychee. J. Amer. Soc. Hort. Sci. 118:161-167.

Torre Grossa, J.P., B.E. Vaissière, G. Rodet, L. Botella, and M. Cousin. 1994. Besoins en pollinisation de la variété d'amandier autocompatible 'Lauranne'. Acta Hort. 373:145-152.

Vargas, F.J., J. Clavé, and M.A. Romero. 2005. Fruit size in self- and open-pollination conditions in self-compatible almond seedlings. IV Intl. Symp. on Pistachios \& Almonds, Tehran, Iran 22-25 May 2005, pp.61-62.
Vezvaei, A. and J.F. Jackson. 1995. Effect of pollen parent and stages of flower development on almond nut production. Austral. J. Expt. Agr. 35:109-113.

Vezvaei, A. and J.F. Jackson. 1996. Almond nut analysis, p. 135-148. In: H.F. Linskens and J.F. Jackson (eds.). Modern methods of plant analysis, Vol. 18: Fruit analysis. Springer-Verlag, Berlin.

Vithanage, V. 1991. Effect of different pollen parents on seedless and quality of 'Ellendale' tangor. Scientia Hort. 48:253-260.

Wallace, H.M. and L.S. Lee. 1999. Pollen source, fruit set and xenia in mandarins. J. Hort. Sci. Biotechnol. 74:82-86. 